\title{
Dolichospermum uruguayense sp. nov., a planktic nostocacean cyanobacteri- um from the Lower Uruguay River, South America
}

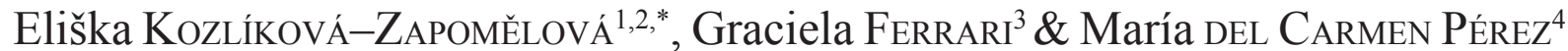

\author{
${ }^{1}$ Biology Centre of AS CR, v.v.i., Institute of Hydrobiology, Na Sádkách 7, CZ-37005 České Budějovice, Czech \\ Republic; *Corresponding author e-mail: eliska.zapomelova@seznam.cz \\ ${ }^{2}$ University of South Bohemia, Faculty of Science, Branišovská 31, CZ-37005 České Budějovice, Czech Re- \\ public \\ ${ }^{3}$ Department of the Environment, Laboratorio Tecnológico del Uruguay (LATU), Avda. Italia, 6201, CP 11500 \\ Montevideo, Uruguay \\ ${ }^{4}$ Phytoplankton Consultant, Montevideo, Uruguay
}

\begin{abstract}
Massive cyanobacterial blooms frequently occur in the Uruguay River, one of the largest rivers in South America. A heterocytous morphospecies of unique morphology has been repeatedly observed in the river since 2006 in rather high abundances. This morphospecies was preliminarily reported as Anabaena spiroides and Dolichospermum cf. pseudocompactum, but its morphology does not fully correspond with the description of these species, neither with definitions of any Dolichospermum species described so far. A clonal strain designated "strain7" was isolated in 2010 from the Lower Uruguay River and thoroughly characterised from morphological and phylogenetic points of view. An establishment of D. uruguayense spec. nov. was proposed.
\end{abstract}

Key words: cyanobacteria, Dolichospermum, phytoplankton, polyphasic approach, taxonomy, Uruguay River, 16S rRNA gene phylogeny

\section{INTRODUCTION}

Cyanobacterial classification has been rapidly developing and has recently undergone substantial revisions. Anabaena-like cyanobacteria represent one of the most complicated groups from the taxonomic point of view.

The traditional genus Anabaena was originally composed of a wide variety of morphospecies with and without gas vesicles. Their classification at the species level was based on morphometric parameters, i.e. length and width of all cell types, their shapes, akinete arrangement and the general morphology of filaments (for the reviews see KomÁreK \& KoMÁrKOVÁ 2006; KoMÁreK \& ZAPOMĚLovÁ 2007, 2008; KomÁreK 2013). However, phylogenetic analyses of planktic (gas-vacuolate) and benthic (non-gas-vacuolate) representatives revealed pronounced differences between these two groups (RAJANIEMI et al. 2005a, b; HaLINEN et al. 2008) and resulted in reclassification of the main phylogenetic clade of planktic morphospecies into the new genus Dolichospermum (RALFs ex Born. et Flah.) Wacklin et al. (Wacklin et al. 2009). Fur- thermore, two separated phylogenetic lineages of the planktic Anabaena-like cyanobacteria were recognized later and new generic entities Sphaerospermopsis ZAPOMĚLOVÁ et al. (ZAPOMĚLOVÁ et al. 2009, 2010a) and Chrysosporum ZAPOMĚLOVÁ et al. (ZAPOMĚLOVÁ et al. 2012) were established.

However, the classification of Dolichospermum at the species level remains unsolved. The genus encompasses approximately 80 freshwater morphospecies (KomÁREK 1996) but many of them are not clearly morphologically delimited (ZAPOMĚLOVÁ et al. 2007, $2008,2009,2010 b)$. A relatively small part of the validly described species has been so far characterized from the phylogenetic point of view. The sequence similarities of $16 \mathrm{~S}$ rDNA and some other genes are very high within this genus (RAJANIEMI et al. 2005a; ZAPOMĚLOVÁ et al. 2011).

The Uruguay River is one of the largest rivers in South America ( $>1,800 \mathrm{~km}$; annual discharge 6,230 $\mathrm{m}^{3} \cdot \mathrm{s}^{-1}$ ). It belongs to the La Plata Basin and forms the boundary of three countries, Brazil, Argentina and Uruguay. One of the main factors affecting the water quality of the Lower Uruguay River is the construction 
of more than twenty hydropower dams. Other human activities, such as increasing urbanization and the expansion of agriculture, have recently favoured the proliferation of massive blooms of planktic cyanobacteria (FERRARI et al. 2011).

The cyanobacterial blooms of the Lower Uruguay River usually contain several Dolichospermum morphospecies. High abundances of a compactly coiled morphospecies, preliminarily reported as $D$. cf. pseudocompactum (FERRARI et al. 2011), have been repeatedly observed in the river since 2006 (Table 1). It commonly occurs mainly along a lower part of the river during spring and summer time (FERRARI et al. 2011). The identical morphospecies was reported under a name Anabaena cf. spiroides from Río de la Plata estuary (Table 1; Sienra \& FerRari 2006). Compactness of filament coiling of this morphospecies is similar to $D$. pseudocompactum WATANABE 1996, but its other morphological features do not fully correspond with the description of this species, neither with definitions of any Dolichospermum species described so far.

The main goal of this study was therefore to provide a detailed polyphasic characterization of the investigated cyanobacterium, to confirm its phylogenetic affiliation to Dolichospermum, to compare it with other Dolichospermum species and to clarify its taxonomic status.

\section{Material And Methods}

Sampling. The studied area comprises three sites along the Lower Uruguay River: Nuevo Berlín (NB), Fray Bentos (FB) and Las Cañas (LC). A transect line was established across the width of the river at each of the three sites, and divided into littoral, center and channel zones in each case. Seasonal samplings were carried out from July 2006 to November 2014 according to a biological monitoring program (BOCCARDI et al. 2010; Ferrari et al. 2011). Two extra samplings were performed in summer 2009 and spring 2010, reflecting the occurrence dynamics of cyanobacterial blooms. To acquire the cyanobacterial strain for purposes of this study, living phytoplankton samples were taken in Fray Bentos site (GPS coordinates: $33^{\circ} 06^{\prime} 24.94$ 'S, $58^{\circ} 15^{\prime} 36.56^{\prime \prime} \mathrm{W}$ ) in November 2010 using a $20-\mu \mathrm{m}$ mesh plankton net. A living sample was used for the strain isolation, cultivation and evaluation of morphology. A non-concentrated sample for quantitative analyses was collected from the same site with a bottle and fixed with Lugol solution, following SouRNIA (1978).

Phytoplankton quantification in environmental samples. The taxonomic identification was carried out with light microscope Olympus CX41, using a 1000× magnification. The organisms were measured and photographed with a DXM 1200 and Infinity 1 digital camera. The counts were performed with an Olympus CKX41 inverted microscope, following the methodology described by UtermöHL (1958). Counts included at least 100 cells of the most abundant species, to yield a confidence interval of $95 \%$ with a counting error under $20 \%$ (LuND et al. 1958).

Isolation and cultivation. A clonal strain was isolated from a sample collected in November 2010 at Fray Bentos sampling site using a glass capillary and an inverted microscope (Olympus IX 71). The strain was designated by a name "strain 7" and maintained in WC medium (GUILLARD \& LORENZEN 1972) under constant culture conditions $\left(21^{\circ} \mathrm{C}\right.$, $70 \mu \mathrm{mol} . \mathrm{m}^{-2} \cdot \mathrm{s}^{-1}$ light intensity, $16 \mathrm{~h} / 8 \mathrm{~h}$ light-dark cycle).

Morphology in the environmental sample and under culture conditions. Morphology of the studied cyanobacterium was evaluated from the environmental sample. Microphotographs of more than 30 fresh trichomes were taken with a digital camera (Olympus DP 70, magnification 400×). Five vegetative cells per trichome were measured in 30 trichomes. Dimensions of heterocytes and akinetes could not be acquired, as these cell types were regularly missing in the environmental sample. But their dimensions were measured previously by FERRARI et al. (2011) in another environmental sample from the Lower Uruguay River (Nuevo Berlín, November 2010). Dimensions of vegetative cells and heterocy-

Table 1. Summary of references on the occurrence of D. uruguayense. References: (1) De León \& Chalar (2003); (2) Sienra \& Ferrari (2006); (3) Chalar et al. (2002); (4) Ferrari unpublished data; (5) Bordet et al. (2012).

\begin{tabular}{|c|c|c|c|c|}
\hline $\begin{array}{l}\text { Taxonomic name given in } \\
\text { the referred literary sources }\end{array}$ & Date & Locality & $\begin{array}{l}\text { Cell density } \\
\left(\text { cells.ml }{ }^{-1}\right)\end{array}$ & References \\
\hline Anabaena sp. & Mar-92 & Salto Grande dam, Uruguay River & 1600 & (1) \\
\hline Anabaena cf. spiroides & 05-Jan-01 & $\begin{array}{l}\text { Ramirez Beach - Montevideo, Río } \\
\text { de la Plata }\end{array}$ & 7960 & (2) \\
\hline Anabaena cf. spiroides & 25-Jan-01 & $\begin{array}{l}\text { Ramirez Beach - Montevideo, Río } \\
\text { de la Plata }\end{array}$ & 412472 & (2) \\
\hline Anabaena sp. & Mar-02 & Salto Grande dam, Uruguay River & n.d. & (3) \\
\hline Anabaena cf. spiroides & 27-Jan-04 & $\begin{array}{l}\text { Pocitos Beach - Montevideo, Río de } \\
\text { la Plata }\end{array}$ & 10000 & (2) \\
\hline Anabaena cf. spiroides & 06-Feb-09 & Fray Bentos, Uruguay River & 418000 & (4) \\
\hline Anabaena sp. & 27-Jan-10 & Salto Grande dam, Uruguay River & 322300 & (5) \\
\hline
\end{tabular}


tes were also measured in the cultivated strain shortly after its isolation. Akinete formation was not observed during the cultivation. Length:width ratios of vegetative cells, heterocytes and akinetes were used as a rough approximation of the cell shapes. All size measurements were performed using image analysis (Olympus DP Soft). Basic statistical characteristics such as mean values, $25 \%$ and $75 \%$ percentiles and extreme values were computed for the morphological parameters.

PCR and sequencing. The 16S rRNA gene and ITS region were amplified directly from a small sample of biomass of strain 7 added to the PCR master mix. The poor growth of the strain in culture made it impossible to obtain a higher amount of biomass for the DNA extraction. Primers 16S27F and 23S30R (TATON et al. 2003) were used and the amplification was carried out as follows: one cycle of $5 \mathrm{~min}$ at $94{ }^{\circ} \mathrm{C}$; 10 cycles of $45 \mathrm{~s}$ at $94^{\circ} \mathrm{C}, 45 \mathrm{~s}$ at $57^{\circ} \mathrm{C}$, and 2 min at $72^{\circ} \mathrm{C}$; 25 cycles of $45 \mathrm{~s}$ at $94{ }^{\circ} \mathrm{C}, 45 \mathrm{~s}$ at $54^{\circ} \mathrm{C}$, and $2 \mathrm{~min}$ at $72^{\circ} \mathrm{C}$; and a final elongation step of $7 \mathrm{~min}$ at $72{ }^{\circ} \mathrm{C}$. PCR product was used as a template for sequencing with primers $16 \mathrm{~S} 27 \mathrm{~F}$, 23S30R (TATON et al. 2003), primer CYA781F(a) (NüBEL et al. 1997), and the reverse complement of Primer 14 (WILMOTTE et al. 1993).

Phylogenetic analyses. Partial sequences of the 16S rRNA gene $(1410 \mathrm{bp})$ were aligned using the program BioEdit version 7.0.9.0 (HALL 1999) and the alignment was edited manually. Phylogenetic trees were constructed by maximum-likelihood (ML) maximum parsimony (MP) and neighbour-joining (NJ) (SAITOU \& NeI 1987) algorithms in the program PAUP* version 4.0b10 (Swofford 2003). The topology for the phylogenetic tree was derived from ML. The $\mathrm{GTR}+\mathrm{I}+\mathrm{G}$ evolutionary model of substitution was found for the best fit to the data using ModelTest 3.7 (PosAdA 2008). The parameters (base frequencies, rate matrix of substitution types and shape of gamma distribution) were estimated from the data. 100, 1000 and 1000 bootstrap replicates were performed for ML, MP and NJ analysis, respectively. The nucleotide sequence was deposited at GenBank under the accession number KC297495. P-distances (\%) based on the 16S rRNA gene sequences (1270 bp) were computed in BioEdit for selected strains representing species morphologically similar to D. uruguayense strain 7 and/or closest megablast matches from GenBank.

Comparison with similar strains from the Czech Republic. Morphology of the Uruguayan strain 7 was compared with selected Dolichospermum strains with coiled trichomes from the Czech Republic that were highly similar both from morphological and phylogenetic points of view. The list of Dolichospermum strains used in this study is provided in Table 2. The polyphasic approach was applied on these strains using the same methods as were used for the

Table 2. Dolichospermum strains used in this study. Abbreviations: (acc. no.) accession number; (CZ) Czech Republic; (D.) Dolichospermum. Detailed characteristics of the strains except of strain 7 were published by ZAPOMĚLOVÁ (2008).

\begin{tabular}{|c|c|c|c|c|c|}
\hline $\begin{array}{l}\text { Strain } \\
\text { code }\end{array}$ & $\begin{array}{l}\text { Species } \\
\text { (morphospecies) }\end{array}$ & Locality name & $\begin{array}{l}\text { Sampling site } \\
\text { GPS coordinates }\end{array}$ & $\begin{array}{l}\text { Year of } \\
\text { isolation }\end{array}$ & $\begin{array}{l}\text { GenBank } \\
\text { acc. no. }\end{array}$ \\
\hline Strain7 & $\begin{array}{l}\text { D. uruguayense } \\
\text { sp. nov. }\end{array}$ & $\begin{array}{l}\text { Lower Uruguay } \\
\text { River, Uruguay }\end{array}$ & $33^{\circ} 6^{\prime} 24.94^{\prime \prime S}, 58^{\circ} 15^{\prime} 36.56^{\prime \prime W}$ & 2010 & KC297495 \\
\hline $04-21$ & D. crassum & $\begin{array}{l}\text { Homolský } \\
\text { fishpond, } \mathrm{CZ}\end{array}$ & $48^{\circ} 57^{\prime} 47.84^{\prime \prime} \mathrm{N}, 14^{\circ} 23^{\prime} 24.96^{\prime \prime} \mathrm{E}$ & 2004 & KC297496 \\
\hline $04-22$ & D. circinale & $\begin{array}{l}\text { Husinec } \\
\text { reservoir, CZ }\end{array}$ & $49^{\circ} 2^{\prime} 17.62^{\prime \prime N}, 13^{\circ} 59^{\prime} 33.80^{\prime \prime} \mathrm{E}$ & 2004 & FN691910 \\
\hline $04-26$ & D. crassum & $\begin{array}{l}\text { Jesenice } \\
\text { reservoir, CZ }\end{array}$ & $50^{\circ} 5^{\prime} 1.88^{\prime \prime N}, 12^{\circ} 28^{\prime} 29.71 " \mathrm{E}$ & 2004 & AM940218 \\
\hline $04-28$ & D. circinale & $\begin{array}{l}\text { Hodějovický } \\
\text { fishpond, CZ }\end{array}$ & $48^{\circ} 56^{\prime} 36.63^{\prime \prime N}, 14^{\circ} 29^{\prime} 35.88^{\prime \prime} \mathrm{E}$ & 2004 & AM940219 \\
\hline 04-29 & D. crassum & $\begin{array}{l}\text { Hodějovický } \\
\text { fishpond, CZ }\end{array}$ & $48^{\circ} 56^{\prime} 36.63^{\prime \prime N}, 14^{\circ} 29^{\prime} 35.88^{\prime \prime} \mathrm{E}$ & 2004 & KC297497 \\
\hline $04-46$ & D. circinale & $\begin{array}{l}\text { Svět fishpond, } \\
\text { CZ }\end{array}$ & $49^{\circ} 0 ' 2.30^{\prime \prime} \mathrm{N}, 14^{\circ} 46^{\prime} 17.05^{\prime \prime} \mathrm{E}$ & 2004 & KC297498 \\
\hline $04-53$ & D. flos-aquae & $\begin{array}{l}\text { Švarcenberk } \\
\text { fishpond, CZ }\end{array}$ & $49^{\circ} 8^{\prime} 52.5^{\prime \prime} \mathrm{N}, 14^{\circ} 42^{\prime} 31.68^{\prime \prime} \mathrm{E}$ & 2004 & FM242088 \\
\hline $04-56$ & D. crassum & $\begin{array}{l}\text { Vajgar fishpond, } \\
\mathrm{CZ}\end{array}$ & $49^{\circ} 8^{\prime} 32.32^{\prime \prime} \mathrm{N}, 15^{\circ} 0^{\prime} 14.22^{\prime \prime} \mathrm{E}$ & 2004 & KC297499 \\
\hline $04-58$ & D. circinale & $\begin{array}{l}\text { Vajgar fishpond, } \\
\mathrm{CZ}\end{array}$ & $49^{\circ} 8^{\prime} 32.32^{\prime \prime N}, 15^{\circ} 0^{\prime} 14.22^{\prime \prime E}$ & 2004 & KC297500 \\
\hline $04-59$ & D. circinale & $\begin{array}{l}\text { Valcha fishpond, } \\
\mathrm{CZ}\end{array}$ & $49^{\circ} 14^{\prime} 34.14^{\prime \prime} \mathrm{N}, 15^{\circ} 10^{\prime} 30.32^{\prime \prime E}$ & 2004 & FN691911 \\
\hline 05-09 & D. crassum & $\begin{array}{l}\text { Římov reservoir, } \\
\mathrm{CZ}\end{array}$ & $48^{\circ} 50^{\prime} 59.94^{\prime \prime} \mathrm{N}, 14^{\circ} 29^{\prime} 29.03^{\prime \prime} \mathrm{E}$ & 2005 & KC297501 \\
\hline
\end{tabular}


strain 7. Their nucleotide sequences were deposited at GenBank under the accession numbers KC297496-KC297501. Morphological and molecular characteristics of strains 04-22, 04-26, 04-28, 04-53, and 04-59 were previously published by ZAPOMĚLOVÁ et al. $(2008,2010 b, 2011)$ while strains 04-21, 04-29, 04-46, 04-56, 04-58, and 05-09 are newly characterized in this study.

\section{RESUlts}

\section{Morphology}

Morphometric characteristics of the studied Dolichospermum morphospecies are summarized in Table 3. Morphologies under natural conditions and during the cultivation are also demonstrated in Figs 1-10.

The Uruguayan Dolichospermum morphospecies displayed compactly coiled trichomes, having the coils closely attached to each other. Pairs and triple strands of trichomes interlaced with each other were frequently observed (Figs 1, 3, 4) and in these cases, coils within one and the same trichome were more distant because of geometric reasons. This could be observed at the ends of these double and triple strands where the filaments were sometimes disentangled (Fig. 9), or in cases where the trichomes were intertwined but their axes of coiling did not overlapped (Figs 3, 4, 10). However, neighbouring coils of the two or three interlaced filaments always touched or were situated very close to each other, analogously to neighbouring coils of solitary trichomes. Vegetative cells were spherical to barrel-shaped, under environmental conditions more or less isodiametric while under culture conditions slightly elongated. Heterocytes and akinetes were extremely rare in natural populations but some heterocytes were observed in culture, where they were spherical or slightly elongated. The mucilaginous envelope was developed only under culture conditions (Figs. 6, 8).

\section{$16 S$ rRNA gene phylogeny}

Phylogenetic analyses based on the 16S rRNA gene sequences revealed that the studied strain appeared within a clade of the genus Dolichospermum. Clustering with the closest megablast matches from GenBank, however, did not receive significant bootstrap supports in any of the three phylogenetic methods used (ML, MP, NJ; Fig. 12). The highest detected percentage $16 \mathrm{SrR}-$ NA gene sequence similarity of the studied strain 7 and some other Dolichospermum strains was $98.3 \%$ (Ta-

Table 3. Morphometric parameters of the original population of the studied Dolichospermum sp., morphology of the isolated strain under culture conditions, and a comparison with morphology of the same Dolichospermum sp. observed by FerRARI et al. (2011). The order of the data is as follows: (minimum) 25\% quartile-mean-75\% quartile (maximum). The values are in micrometers ( $\mu \mathrm{m}$ ), except of the length:width ratios that are absolute values.

\begin{tabular}{|c|c|c|c|}
\hline Morphometric parameters & $\begin{array}{l}\text { Original natural population } \\
\text { (November 2010) }\end{array}$ & $\begin{array}{l}\text { Isolated strain (strain 7) } \\
\text { (isolated in November } \\
\text { 2010, measured in May } \\
\text { 2012) }\end{array}$ & $\begin{array}{l}\text { Morphology observed } \\
\text { in } 2009 \text { in the Uruguay } \\
\text { River (FERRARI et al., } \\
2011 \text { ) }\end{array}$ \\
\hline \multicolumn{4}{|l|}{ Vegetative cells } \\
\hline Length $(\mu \mathrm{m})$ & (4.7) 7.0-8.1-9.8 (12.0) & (5.4) 8.9-9.5-10.8 (12.3) & $6.0-8.0$ \\
\hline Width $(\mu \mathrm{m})$ & (7.1) 8.1-8.6-8.9 (9.7) & (7.1) 8.2-8.8-9.8 (11.1) & $7.6-8.3$ \\
\hline Length:width ratio & (0.5) 0.8-1.0-1.1 (1.5) & (0.6) 1.0-1.1-1.2 (1.4) & \\
\hline \multicolumn{4}{|l|}{ Heterocytes } \\
\hline Length $(\mu \mathrm{m})$ & n.o. & (8.8) 9.8-10.6-11.3 (13.3) & $9.0-12.0$ \\
\hline Width $(\mu \mathrm{m})$ & n.o. & (8.1) 9.3-10.2-10.7 (11.7) & $9.0-12.0$ \\
\hline Length:width ratio & n.o. & (1.0) 1.0-1.1-1.1 (1.2) & \\
\hline \multicolumn{4}{|l|}{ Akinetes } \\
\hline Length $(\mu \mathrm{m})$ & n.o. & n.o. & $22.3-25.0$ \\
\hline Width $(\mu \mathrm{m})$ & n.o. & n.o. & $10.0-12.6$ \\
\hline Length:width ratio & n.o. & n.o. & \\
\hline Trichome coiling Diameter & (19.6 ) 28.4-29.5-30.8 (41.2) & (22.6) 26.7-28.5-30.1 (33.0) & $27.0-30.0$ \\
\hline Distance & (0.0) 0.0-0.2-0.7 (3.0) & (0.0) 0.2-0.4-1.2(3.0) & \\
\hline
\end{tabular}



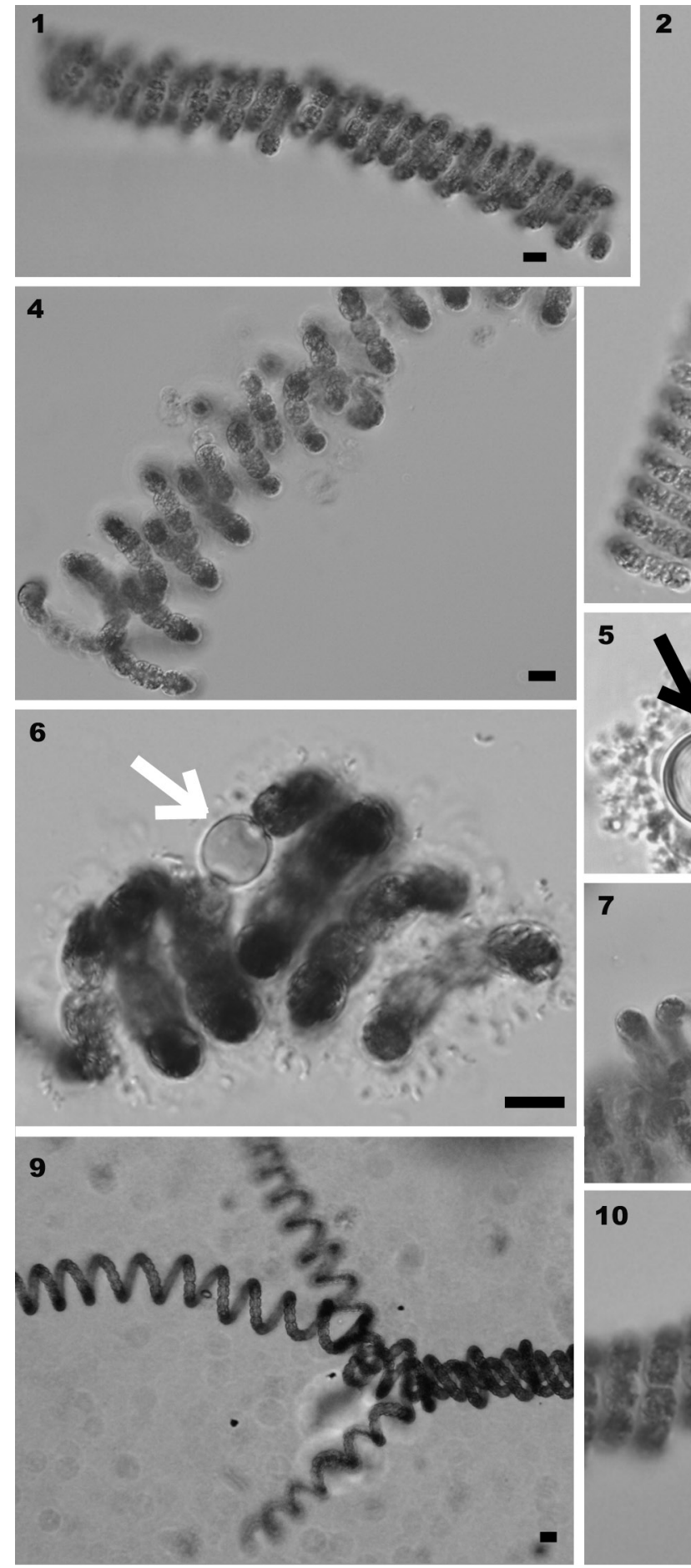

2

10
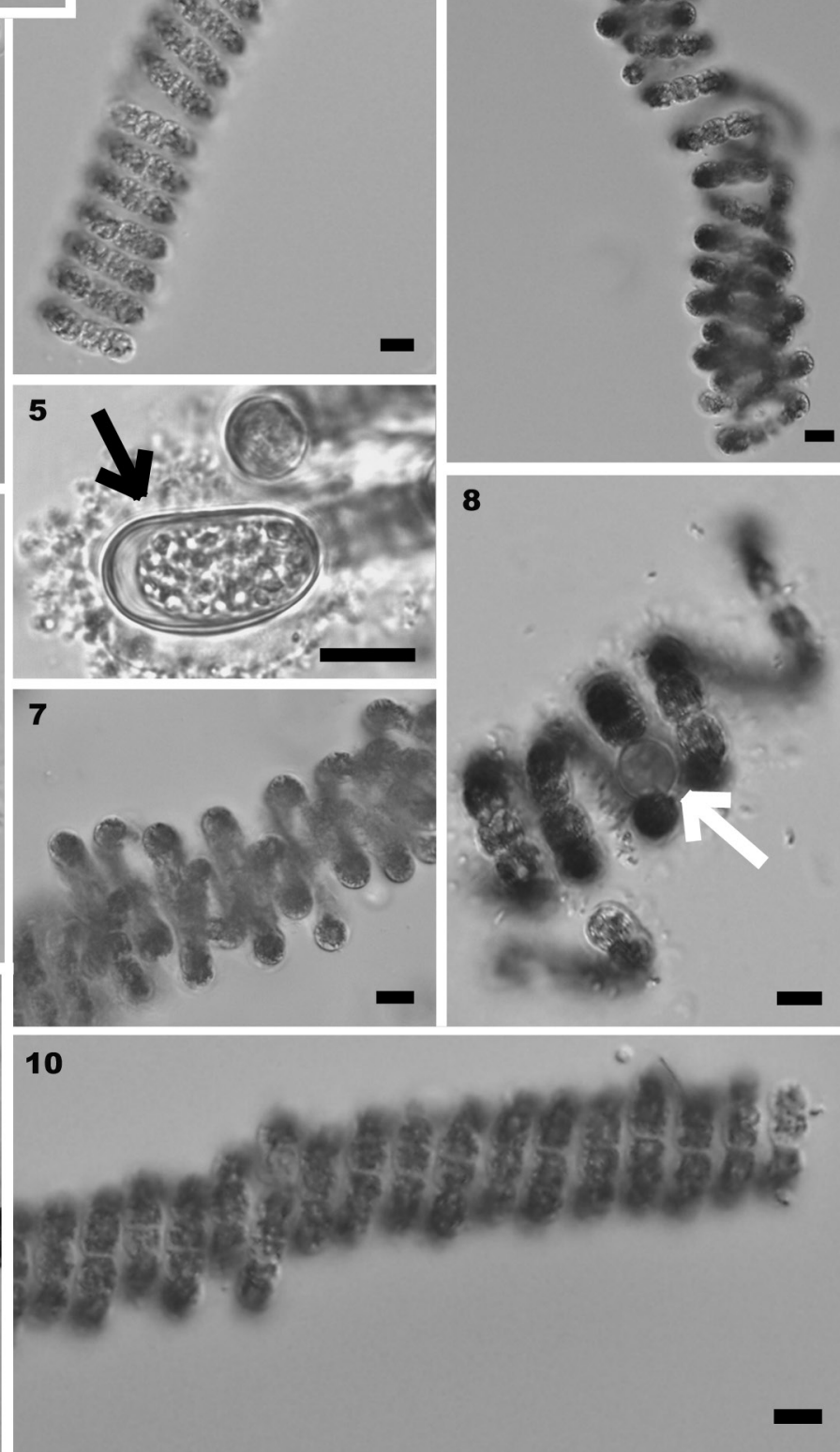

Fig. 1-10. The studied Dolichospermum morphospecies under natural conditions $(1-5,7,9,10)$ and in culture (6, 8). Fig. 9 by HAAKONSSON \& PÉREZ. Scale bars represent $10 \mu \mathrm{m}$. Symbols: white arrows, heterocytes; black arrow, akinete.

ble 4; strains of D. circinale, D. mucosum, D. smithii, $D$. spiroides, and $D$. viguieri). The similarity with $D$. pseudocompactum was $97.3 \%$ (Table 4 ).

\section{Morphological comparison of strain 7 and similar strains from the Czech Republic}

The majority of the closest megablast matches from GenBank with the Uruguayan strain 7 were Dolichospermum strains from the Czech Republic. We therefore performed a detailed morphological comparison of the most similar strains that clustered together with strain 7 in the phylogenetic tree (cluster 1, Fig. 12) to see how similar or different the morphology of strain 7 is.

Vegetative cell length of strain 7 was comparable with Czech strains from the morphological complex of species $D$. circinale and D. crassum while its vegetative cell width was at the lower limit of their diversity (Fig. 13). 
Similarly, akinete length of the Uruguayan cyanobacterium was comparable with Czech $D$. circinale and $D$. crassum strains. On the contrary, its akinetes were obviously narrower than akinetes of the Czech D. circina$l e$ and $D$. crassum strains. The values of akinete width of strain 7 lay somewhere between akinete widths of the $D$. circinale / D. crassum strains and the strain $D$. flos-aquae 04-53 (Fig. 13).

Trichome coil diameters of strain 7 were at the lower limit of coil diameters of Czech $D$. circinale and D. crassum strains. The distances between adjacent trichome coils of strain 7 were significantly lower than coil distances in all other strains used for the comparison in this study. This parameter ranged from $0.0 \mu \mathrm{m}$ to $3.0 \mu \mathrm{m}$ (mean value $0.2 \mu \mathrm{m}$ ) in solitary trichomes of strain 7, while trichome coil distance of $D$. flos-aquae 04-53 strain was 3.8-12.3 $\mu \mathrm{m}$ (mean value $8.3 \mu \mathrm{m}$ ). This parameter was even higher in the $D$. circinale and D. crassum strains: $12-94 \mu \mathrm{m}$, with mean values between $22.2 \mu \mathrm{m}$ and $67.3 \mu \mathrm{m}$ (depending on the strain; Fig. 14).

Occurrence frequency of the studied Dolichospermum sp. in the Lower Uruguay River

The occurrence of the studied Dolichospermum morphospecies in the Lower Uruguay River has been reported since 2006 during spring and summer (Table $5)$. The highest abundance $\left(4.2 \times 10^{5}\right.$ cells.ml $\left.{ }^{-1}\right)$ was observed during a Microcystis aeruginosa bloom near Fray Bentos site in summer 2009.

\section{Discussion}

Morphological features of the studied strain from Uruguay did not correspond to any of the Dolichospermum species described so far. The dimensions of all cell types, in combination with kidney-shaped akine- tes, distinguish it from other compactly coiled species like D. pseudocompactum, D. compactum, Anabaena eucompacta, and Sphaerospermopsis reniformis. Regarding dimensions of all cell types, the most similar species to strain 7 appears to be $D$. circinale and $D$. crassum (Table 6). The specific characteristic of the Uruguayan morphospecies, however, is the compact trichome coiling and kidney-shaped akinetes.

The pronounced morphological difference of strain 7 was also apparent in comparison with the closest GenBank megablast matches. D. circinale and D. crassum strains and a strain of D. flos-aquae 04-53 from the Czech Republic differed from strain 7 in the morphology of trichome coiling. Morphologies of other closest matches such as D. affine, D. planctonicum, D. smithii, and D. viguieri were markedly different. D. affine, D. planctonicum, D. smithii, and $D$. viguieri strains were characterized by straight trichomes, $D$. affine formed typical bundles of trichomes (morphology of these strains published by ZAPOMĚLOVÁ et al. 2011).

The highest detected percentage 16S rRNA gene sequence similarity between the studied strain 7 and another Dolichospermum representative was 98.3 $\%$ (Table 4). At present, a prokaryotic species is considered to be a group of strains (including the type strain) that are characterized by a certain degree of phenotypic consistency, showing over $97 \%$ of 16 S ribosomal RNA (rRNA) gene-sequence identity (VANDAMmE et al. 1996). From this point of view, strain 7 does not fulfill the conditions to be considered a separate species, as its similarity to other Dolichospermum species is higher than $97 \%$. On the other hand, even higher similarities can be observed among obviously different and accepted species within the genus Dolichospermum (Table 4).

To describe and unambiguously classify the unique morphospecies of Dolichospermum from the

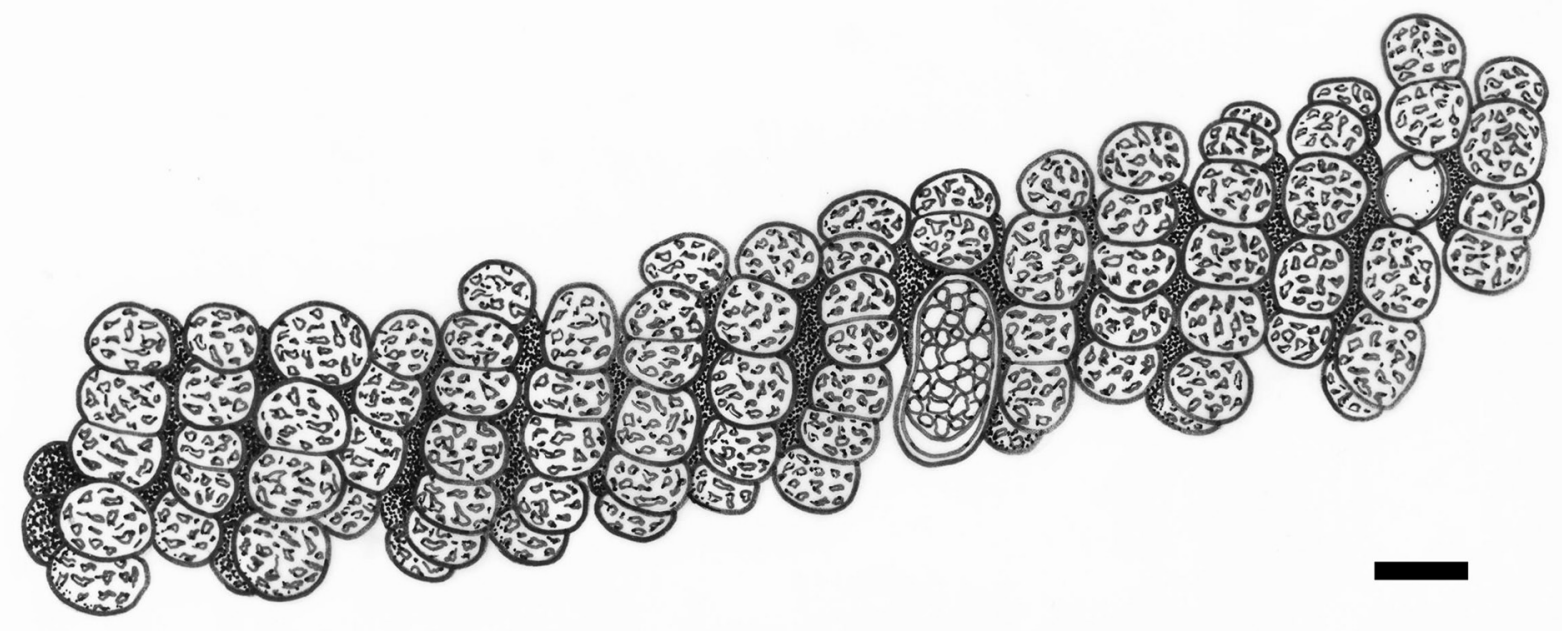

Fig. 11. Dolichospermum uruguayense, morphology of trichome coiling, vegetative cells, a heterocyte and an akinete. The scale bar represents $10 \mu \mathrm{m}$. Holotype. 
Table 4. Matrix showing P-distances (\%) based on the 16S rRNA gene sequences (1270 bp). All positions containing alignment gaps were only eliminated in pairwise sequence comparison. Strains representing species morphologically similar to D. uruguayense strain 7 were selected for the matrix, as well as representatives of cluster 1 of the herein presented phylogenetic tree (Fig. 12). The studied strain D. uruguayense strain 7 is in bold.

\begin{tabular}{|c|c|c|c|c|c|c|c|c|c|c|c|c|c|}
\hline & & 1 & 2 & 3 & 4 & 5 & 6 & 7 & 8 & 9 & 10 & 11 & 12 \\
\hline 1 & $\begin{array}{l}\text { D. uruguayense } \\
\text { strain } 7\end{array}$ & & & & & & & & & & & & \\
\hline 2 & D. pseudocompactum & 97.3 & & & & & & & & & & & \\
\hline 3 & $\begin{array}{l}\text { TAC } 538 \\
\text { D. compactum } 04-17\end{array}$ & 97.2 & 97.7 & & & & & & & & & & \\
\hline 4 & $\begin{array}{l}\text { D. compactum } \\
\text { ANACOM-KOR }\end{array}$ & 97.2 & 97.7 & 100.0 & & & & & & & & & \\
\hline 5 & D. flos-aquae $04-53$ & 98.0 & 98.1 & 98.3 & 98.3 & & & & & & & & \\
\hline 6 & D. affine 04-44 & 98.0 & 98.7 & 98.4 & 98.4 & 98.9 & & & & & & & \\
\hline 7 & D. affine $05-03$ & 97.6 & 98.6 & 98.3 & 98.3 & 98.8 & 99.8 & & & & & & \\
\hline 8 & D. circinale $04-21$ & 98.3 & 98.2 & 98.0 & 98.0 & 98.7 & 99.0 & 98.7 & & & & & \\
\hline 9 & D. circinale $04-56$ & 98.1 & 98.2 & 97.9 & 97.9 & 98.7 & 99.0 & 98.7 & 99.7 & & & & \\
\hline 10 & D. muсоsит 08-09 & 98.3 & 98.3 & 98.0 & 98.0 & 98.7 & 99.1 & 98.9 & 99.8 & 99.8 & & & \\
\hline 11 & D. smithii $05-05$ & 98.3 & 98.3 & 97.9 & 97.9 & 98.7 & 99.1 & 98.8 & 99.9 & 99.8 & 99.9 & & \\
\hline 12 & D. spiroides $04-51$ & 98.3 & 97.8 & 97.5 & 97.5 & 98.1 & 98.6 & 98.3 & 99.3 & 99.4 & 99.4 & 99.4 & \\
\hline 13 & D. viguieri $08-04$ & 98.3 & 98.1 & 97.8 & 97.8 & 98.6 & 98.9 & 98.7 & 99.8 & 99.8 & 99.8 & 99.8 & 99.4 \\
\hline
\end{tabular}

Uruguay River, a taxonomic name is necessary. We decided to erect a new species because we suppose an establishment of a variety would not be appropriate in this case, as it is unclear which one of the existing species should include this potential variety. As was demonstrated in this study, the Dolichospermum morphospecies from the Uruguay River differs from all existing species, although morphological similarities with several of them can be found.

Akinetes and heterocytes of this new Dolichospermum species are extremely rare in natural populations and we therefore decided to select a figure as a holotype instead of a preserved sample. This is in accordance with rules of the International Code of Nomenclature for Algae, Fungi and Plants (Art. 40.5.; McNeILl et al., 2012). The species is well recognizable in natural samples even without the specialized cells, according to the typical morphology of trichome coiling. We tried to induce heterocyte and akinete formation of strain 7 in culture conditions (desiccation, modified $\mathrm{N}$ or $\mathrm{P}$ concentrations, varied light intensities). Heterocytes differentiated easily under low nitrogen while we did not manage to induce akinete formation. This indicates the low ability to form akinetes might be an ecological or ecophysiological feature of this species, or maybe a genetic feature or a kind of adaptation.

This species has been reported from the lower Uruguay river (Table 5) and from the Río de la Plata estuary (SIENRA \& FERRARI 2006), in both cases during spring and summer periods, reaching high densities together with other cyanobacteria as Microcystis aeruginosa. Abundances observed in January 2001 in Río de la Plata, in February 2003 and 2009 at Fray Bentos site and in January 2010 at Salto Grande dam, Uruguay River (Table 1, Table 5) demonstrate that this cyanobacterium can even dominate water blooms, which has to be considered when the role of this species in the ecosystem is assessed or discussed.

Dolichospermum uruguayense, sp. nov. KozLíKovÁZapomělová, Ferrari et Pérez

Description: Coiled trichomes of varying length, not attenuated towards ends, without mucilaginous sheaths, solitary or in couples and sporadically in triples, one filament twisted inside another (Figs. 3, 4, $7,9)$, constricted at the cell walls. Diameter of coiling (19.6) 28.4-29.5-30.8 (41.2) $\mu \mathrm{m}$, distances between adjacent coils of solitary filaments $0.0-0.2-3.0$ $\mu \mathrm{m}$. Terminal cells undifferentiated. Vegetative cells with finely granular contents and aerotopes, spherical or barrel-shaped, compressed during division, (7.1) 8.1-8.6-8.9 (9.7) $\mu \mathrm{m}$ wide. Heterocytes only intercalary, solitary, spherical, (8.1) 9.3-10.2-10.7 (11.7) $\mu \mathrm{m}$ wide. Akinetes kidney-shaped, 22.3-25.0 $\mu \mathrm{m}$ long and 10.0-12.6 $\mu \mathrm{m}$ wide, distant from heterocytes, very rare both in the natural population and under culture conditions. Planktic. 
Table 5. Average abundance of Dolichospermum uruguayense (cells. $\mathrm{mL}^{-1}$ ) in the Uruguay River from October 2006 to November 2014 at three sampling sites.

\begin{tabular}{llll}
\hline & $\begin{array}{l}\text { Nuevo } \\
\text { Berlín }\end{array}$ & $\begin{array}{l}\text { Fray } \\
\text { Bentos }\end{array}$ & Las Cañas \\
\hline Oct-06 & 55 & 30 & 16 \\
Nov-07 & 27 & 82 & \\
Feb-08 & 509 & 624 & 1451 \\
Feb-09 & 68 & 143380 & 108 \\
Feb-10 & & 30 & \\
Nov-10 & 6903 & 1414 & 1597 \\
Feb-11 & 83 & 11 & \\
Nov-11 & 1164 & 494 & 816 \\
Feb-13 & 29 & 29 & 29 \\
Nov-14 & & & 13 \\
\hline
\end{tabular}

Autapomorphic characteristics: Compactness of trichome coiling in combination with the dimensions of vegetative cells and akinete shape.

Etymology: The name of the species is derived from the Uruguay River, South America, from where the type population was described.

Holotype: In accordance with rules of the International Code of Nomenclature for Algae, Fungi and Plants (Art. 40.5.; McNeILl et al., 2012) represented by dried material A-055-1, herbarium CBFS, University of South Bohemia, České Budějovice, Czech Republic.

Iconotype: Fig. 11.

Type strain: deposited in two official culture collections: CCALA, Institute of Botany, AS CR, Třeboň, Czech Republic, accession no. CCALA987; Culture Collection of Algae at Goettingen University (SAG), Goettingen, Germany, accession no. SAG 2498.

Diagnosis: Trichomata libere natantia, brevia vel longa, circinata, ad apices non attenuata, sine vaginis mucosis, solitaria vel paralleliter in duos vel tres conjunctae, inter trichomatibus aliis spiralis intermixta vel contorta, ad septa constricta; spirae (19.6) 28.4-29.5-30.8 (41.2) $\mu \mathrm{m}$ latae, dense dispositae, ad trichomata solitaria 0.0-0.2-3.0 $\mu \mathrm{m}$ distantes; cellulae sphericae vel barriliformes, plus minusve isodiametricae, (7.1) 8.1-8.6-8.9 (9.7) $\mu$ m latae, ante divisionem depressae, ad apices trichomatis non dissimiles. Protoplasmate subtiliter granulari cum aerotopis. Heterocytae et akineta rare. Heterocytae intercalares, sphaericae, solitariae (8.1) 9.3-10.2-10.7 (11.7) $\mu \mathrm{m}$ latae. Akineta reniformia, 22.3-25.0 × 10.0-12.6 $\mu \mathrm{m}$, ab heterocytis remota.

Holotypus: Figura nostra 11.
Locus classicus: In plancto fluminis Uruguay, Uruguay, America Meridionalis.

Ethymologia: Species secundum locum classicum nominata.

\section{ACKNOWLEDGEMENTS}

The authors would like to thank to Prof. Jiří Komárek and Dr. Jaroslava Komárková for valuable comments and discussions about taxonomic issues. We are grateful to Marie Kupková and Jindra Bučková for the technical assistance, to Macarena Silva who took the water sample in the right moment, to UPM pulp mill in Fray Bentos for the permission to use of monitoring results, and to Dr. A. Comas for his Latin corrections. This study was largely supported by Grant Agency of the Czech Republic (GACR) project No. P504/10/1501. Partial financial assistance was provided by GACR project No. P504/14/18067S and by institutional support RVO:60077344. M. C. Pérez was assisted with a grant from de ANII-LATU, Uruguay, project PR_VCT_2008_09.

\section{REFERENCES}

Bordet, F.; López, C. \& Panozzo, V. (2012): Monitoreo de emergencia Floraciones de cianobacterias: Area recreativa de Salto Grande [Emergency Monitoring cyanobacteria blooms : Recreational area of Salto Grande]. - In: Material recopilado por el área Gestión Ambiental de la Gerencia de Ingeniería y Planamiento de la Comisión [Material compiled by the Environmental Management area of Engineering and Management of Salto Grande Commission]. Programas Ambientales de Salto Grande, ArgentinaUruguay . - pp.11-25, Salto, Uruguay.

Boccardi, L.; Clemente, J.; Dabezies, M.; Ferrari, G.; Saizar, C.; Miguez, D.; Teixeira-De Mello, F. \& TANNA, J. (2010): Línea de base para evaluar el impacto de la planta de celulosa en el Río Uruguay [Baseline studies for a pulp mill environmental impact assesment on the Uruguay River]. - Revista del Laboratorio Tecnológico del Uruguay $\mathrm{n}^{\circ} 5$, INNOTEC, Montevideo: 5-22.

Chalar, G.; De León, L.; Brugnoli, E.; Clemente, J. \& PaRADISO, M. (2002): Antecedentes y nuevos aportes al conocimiento de la estructura y dinámica del Embalse Salto Grande [Background and new contributions to the knowledge of the structure and dynamics of the Salto Grande Reservoir]. - In: A. FernándEZ-CIRELLi \& G. Chalar (eds): El agua en Sudamérica: de la Limnología a la Gestión en Sudamérica [Water in South America: Limnology of the Management in South America]. - pp. 123-142, CYTED Aprovechamiento y Gestión de los Recursos Hídricos, Buenos Aires.

De León, L. \& Chalar, G. (2003): Abundancia y diversidad del fitoplancton en el embalse de Salto Grande (Argentina - Uruguay). Ciclo estacional y distribución espacial. [Phytoplankton abundance and diversity in the Salto Grande reservoir (Argentina-Uruguay). [Seasonal cycle and spatial distribution]. - Limnetica 22: 103-113.

Elenkin, A. A. (1938): Monographia algarum cyanophycearum aquidulcium et terrestrium in finibus URSS inventarum. (Sinezelenyje vodorosli SSSR). - pp. 1908., Izd. AN SSSR, Moskva, Leningrad. 


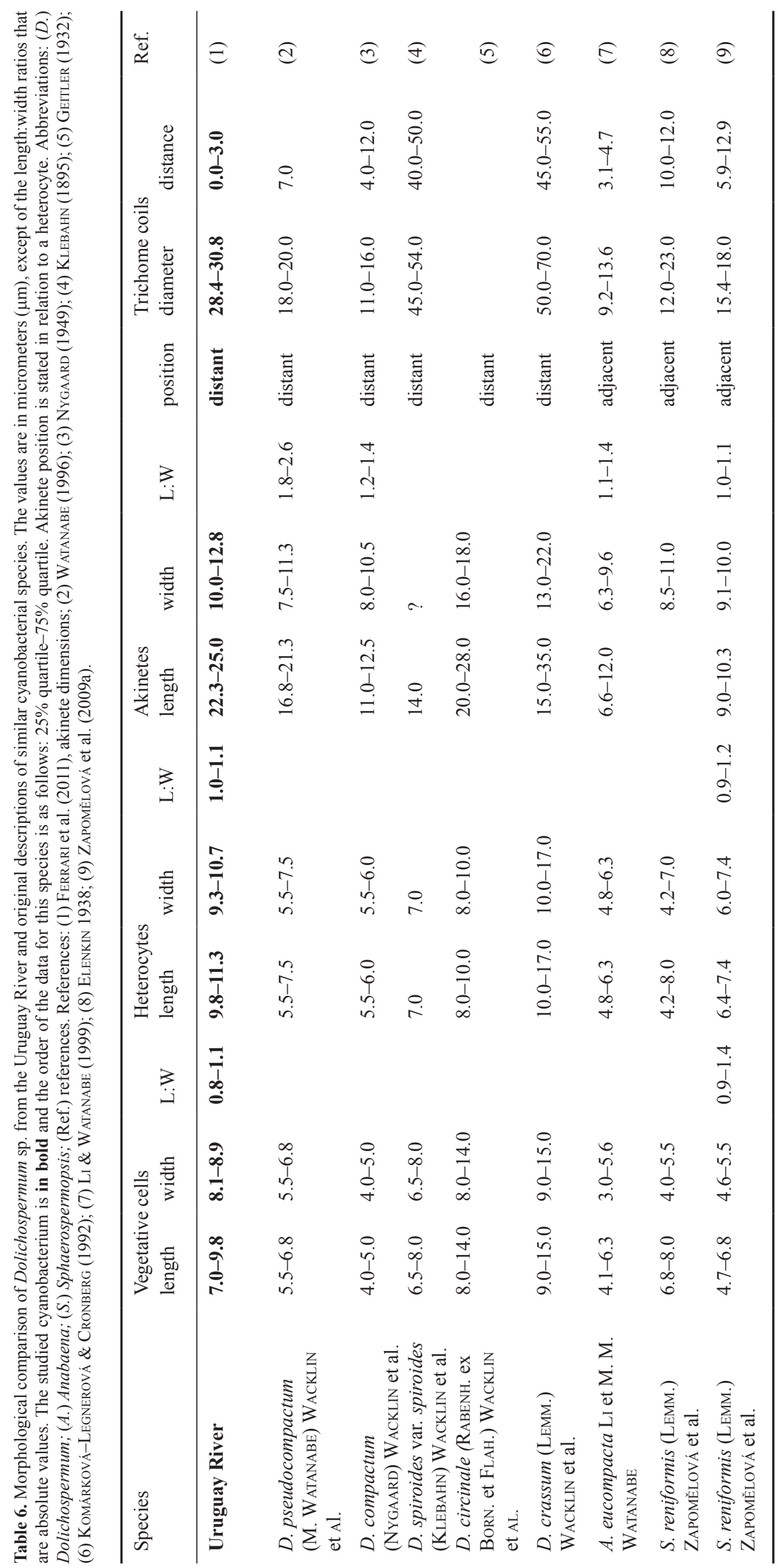




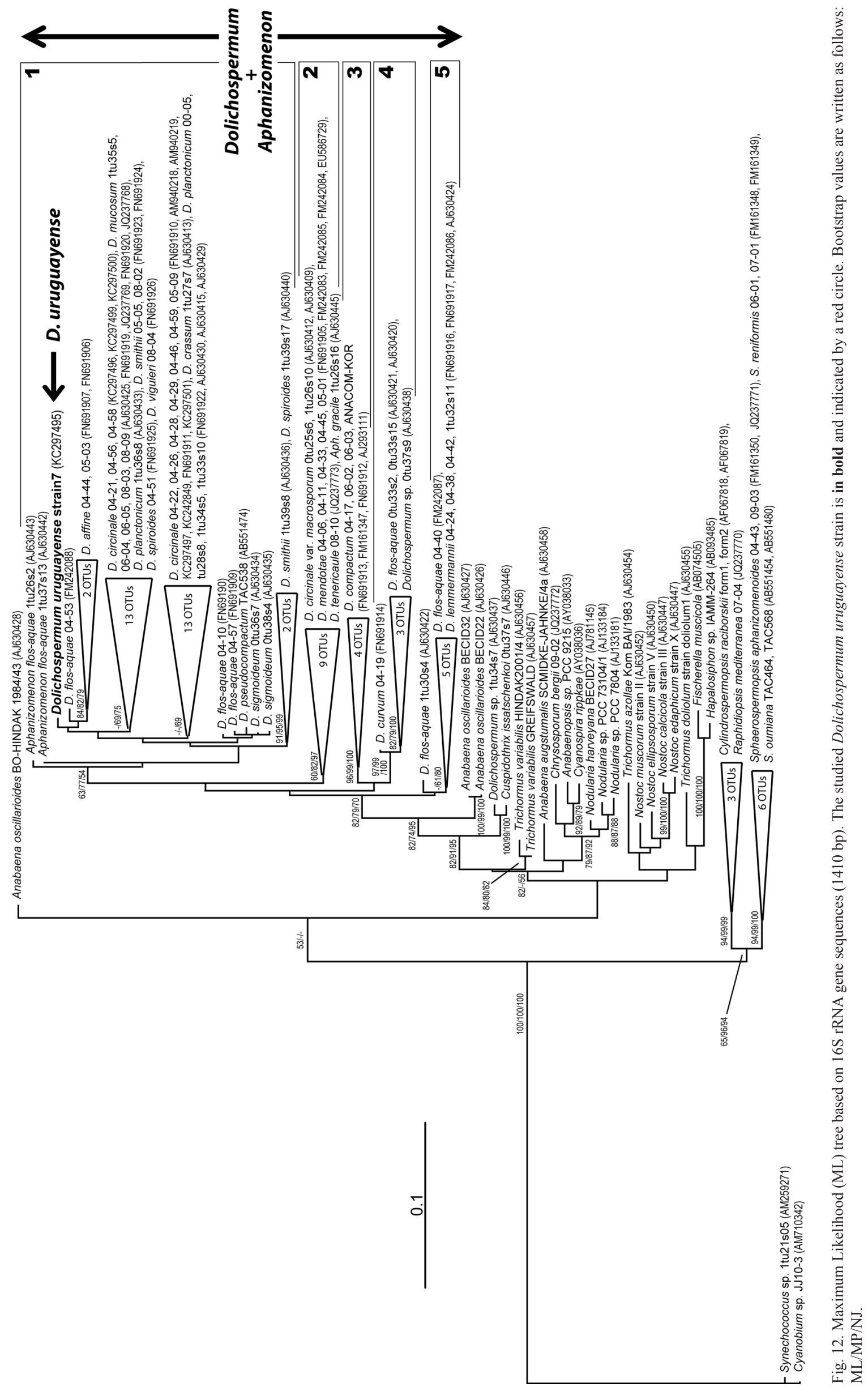



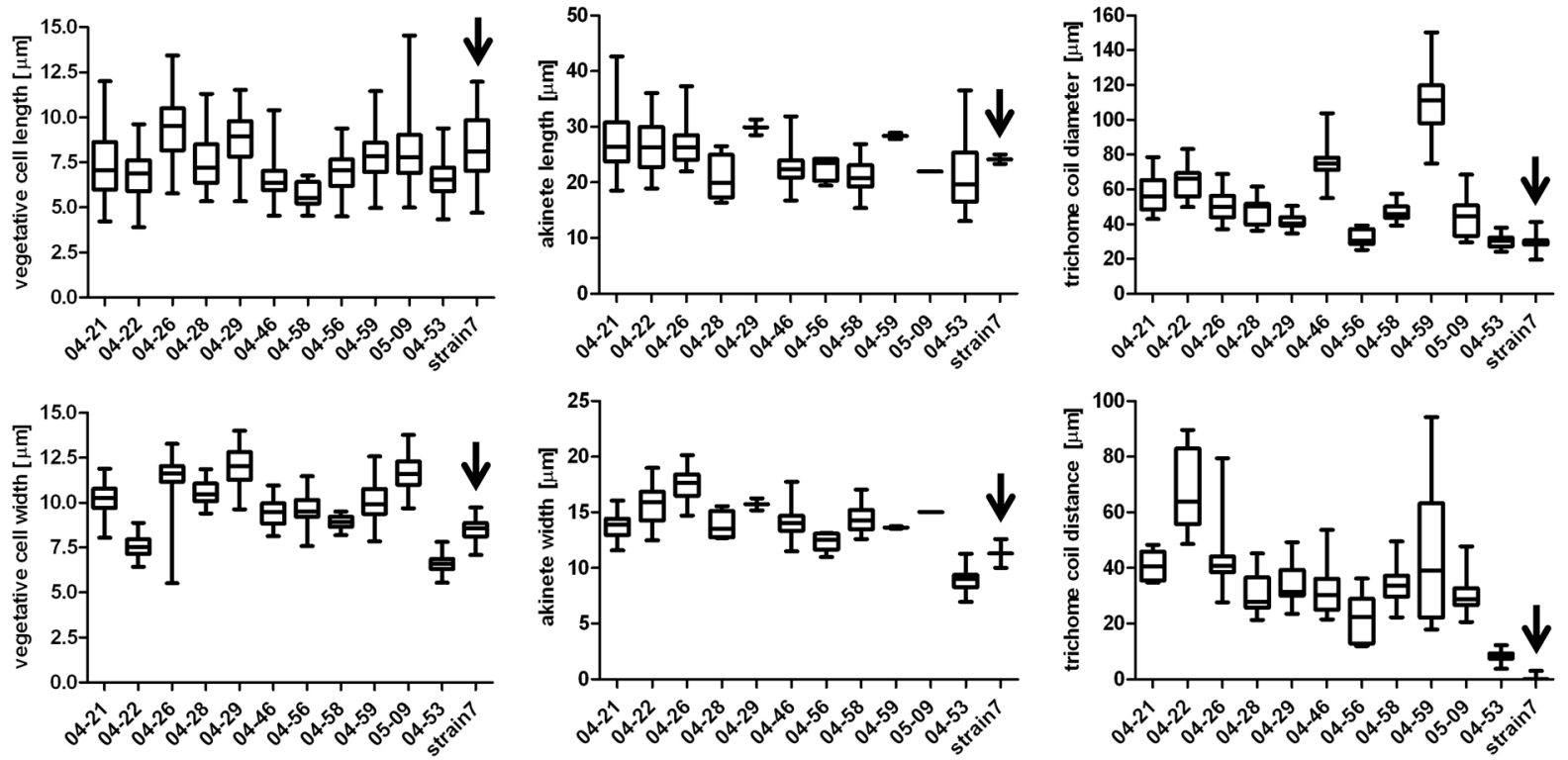

Fig. 13. Morphological comparison of D. uruguayense strain 7 (indicated by arrows) and similar strains from the Czech Republic (for their detailed characterization see Table 2). All of these strains clustered together in cluster 1 of the ML phylogenetic tree based on the 16S rRNA gene sequences (Fig. 12). Whiskers represent minimal and maximal values, boxes symbolize $25 \%$ and $75 \%$ percentiles and lines inside boxes show mean values.

Ferrari, G.; Pérez, M. C.; Dabezies, M.; Míguez, D. \& SaIZAR, C. (2011): Planktic cyanobacteria in the Lower Uruguay River, South America. - Fottea 11: 225234.

Geitler, L. (1932): Cyanophyceae. - 1196 pp., Berlin: Koeltz Scientific Books.

Guillard, R.R.L. \& Lorenzen, C.J. (1972): Yellow-green algae with chlorophyllide c. - J. Phycol. 8: 10-14.

Halinen, K.; Fewer, D.P.; Sihvonen, L.M.; Lyra, C.; Eronen, E. \& Sivonen, K. (2008): Genetic diversity in strains of the genus Anabaena isolated form planktonic and benthic habitats of the Gulf of Finland (Baltic Sea). FEMS Microbiol. Ecol. 64: 199-208.

HALl, T.A. (1999): BioEdit: a user-friendly biological sequence alignment editor and analysis program for Windows 95/98/NT. - Nucl. Acids. Symp. Ser. 41: 95-98.

KLebahn, H. (1895): Gasvacuolen ein Bestandteil der Zellen der wasserblütebildenden Phycochromaceen. - Flora 80: 241-282.

KomÁReK, J. (1996): Klíč k určování vodních květů sinic v České republice [A key for determination of water-bloom-forming cyanobacteria in the Czech Republic]. In: MaršÁleK, B.; Keršner, V. \& Marvan, P. (eds): Vodní květy sinic [Cyanobacterial water blooms] - pp. 22-85, Nadatio flos-aquae, Brno.

KomÁReK, J. (2013): Süßwasserflora von Mitteleuropa, Bd. 19/3: Cyanoprokaryota: 3. Teil / 3rd part: Heterocytous Genera. - 1130 pp., Springer Spectrum.

KomÁReK, J. \& KomÁrkovÁ, J. (2006): Diversity of Aphanizomenon-like cyanobacteria. - Czech Phycology, Olomouc 6: 1-32.

KomÁReK, J. \& ZAPOMĚLovÁ, E. (2007): Planktic morphospecies of the cyanobacterial genus Anabaena $=$ subg. Dolichospermum - 1. part: coiled types. - Fottea 7: 1-31.

KomÁREK, J. \& ZAPOMĚLovÁ, E. (2008): Planktic morphospe- cies of the cyanobacterial genus Anabaena $=$ subg. Dolichospermum - 2. part: straight types.- Fottea 8: $1-14$.

KomÁrková-Legnerová, J. \& Cronberg, G. (1992): New and recombined filamentous Cyanophytes from lakes in South Scania, Sweden. - Algol. Stud. 67: 21-31.

Laboratotio Tecnológico del Uruguay (LATU) (2009): Informe sobre la floración en el Río Uruguay [Report about cyanobacterial bloom in the Uruguay River]. 5 pp., Assay Report No. 22099 LATU, Montevideo.

LI, R. \& Watanabe, M.M. (1999): Anabaena eucompacta sp. nov. (Nostocales, Cyanobacteria), a new planktonic species with tightly spiraled filaments from Japan. Bull. Natn. Sci. Mus., Tokyo, Ser. B 25: 89-94.

Lund, J. W. G.; Kipling, C. \& Le Cren, E. D. (1958): The inverted microscope method of estimating algal numbers and the statistical basis of estimations by counting. - Hydrobiologia 2: 143-170.

McNeill, J.; Barrie, F. R.; Buck, W. R.; Demoulin, V.; GreuTER, W.; Hawksworth, D. L.; Herendeen, P. S.; KNApp, S.; Marhold, K.; Prado, J.; Prud'Homme van Reine, W. F.; Smith, G. F.; Wiersema, J. H. \& Turland, N. J. (2006): International Code of Nomenclature for algae, fungi, and plants (Melbourne Code). Electronic version of the original English text, adopted by the Eighteenth International Botanical Congress Melbourne, Australia, July 2011. International Association for Plant Taxonomy. -http://www.iapt-taxon. org/nomen/main.php

Nübel, U.; Garcia-Pichel, F. \& Muyzer, G. (1997): PCR primers to amplify $16 \mathrm{~S}$ rRNA genes from cyanobacteria. - Appl. Env. Microbiol. 63: 3327-3332.

NyGAARD, G. (1949): Hydrobiological studies on some Danish ponds and lakes. Kong. - Danske Vidensk. Selskab., Biol. Skr. 7: 1-293.

Posada, D. (2008): ModelTest: phylogenetic model averaging. - Mol. Biol. Evol. 25: 1253-1256. 
Rajaniemi, P.; Hrouzek, P.; Kaštovská, K.; Willame, R.; Rantala, A.; Hoffmann, L.; Komárek, J. \& SivoNEN, K. (2005a): Phylogenetic and morphological evaluation of the genera Anabaena, Aphanizomenon, Trichormus and Nostoc (Nostocales, Cyanobacteria). - Int. J. Syst. Evol. Microbiol. 55: 11-26.

Rajaniemi, P.; KomÁreK, J.; Willame, R.; Hrouzek, P.; Kaštovská, K.; Hoffmann, L. \& Sivonen, K. (2005b): Taxonomic consequences from the combined molecular and phenotype evaluation of selected Anabaena and Aphanizomenon strains. - Algol. Stud. 117: 371-391.

SAitou, N. \& NeI, M. (1987): The neighbor-joining method: a new method for reconstructing phylogenetic trees. - Mol. Biol. Evol. 4: 406-425.

Sienra, D. \& Ferrari, G. (2006): Monitoreo de cianobacterias en la costa de Montevideo. [Cyanobacteria monitoring in the Montevideo coast]. - In: MENAFra, R.; Rodriguez-Gallego, L.; Scarabino, F. \& Conde, D. (eds): Bases para la conservación y el manejo de la costa uruguaya [Conservation and mangement bases in the Uruguayan coast]. Vida Silvestre, Uruguay. [Wildlife Uruguay] - pp. 413-419, Montevideo.

SourniA, A. (1978): Phytoplankton manual. - 337 pp., Monographs on oceanographic methodology 6. UNESCO, Paris.

Swofford, D.L. (2003): PAUP*. Phylogenetic Analysis Using Parsimony (*and other methods). Version 4b10. - Sunderland, MA: Sinauer Associates.

Taton, A.; Grubisic, S.; Brambilla, E.; De Wit, R. \& Wilмотте, A. (2003): Cyanobacterial diversity in natural and artificial microbial mats of Lake Fryxell (McMurdo dry valleys, Antarctica): A morphological and molecular approach. - Appl. Env. Microbiol. 69: 5157-5169.

UtermöHL, H. (1958): Zur Vervollkommnung der quantitativen Phytoplankton Methodik. [Contribution to the improvement of methodology of phytoplankton quantification]. - Mitt. Int. Verein. Limnol. 9: 1-38.

Vandamme, P.; Рot, B.; Gillis, M.; DeVos, P.; Kersters, K. \& Swings, J. (1996): Polyphasic taxonomy, a consensus approach to bacterial systematics. - Microbiol. Rev. 60: 407-438.

Wacklin, P.; Hoffmann, L. \& KomÁreK, J. (2009): Nomenclatural validation of the genetically revised cyanobacterial genus Dolichospermum (Ralfs ex Bornet et Flahault) comb. nova. - Fottea 9: 59-64.

Watanabe, M. (1996): Studies on planktonic blue-green algae 7. Anabaena pseudocompacta sp. nov. From eutrophic lakes in central Japan. - Bull. Natn. Sci. Mus., Tokyo, Ser. B 22: 93-97.

Wilmotte, A.; Van der Auwera, G. \& De Wachter, R. (1993): Structure of the 16S ribosomal RNA of the thermophilic cyanobacterium Chlorogloeopsis HTF
('Mastigocladus laminosus HTF') strain PCC7518, and phylogenetic analysis. - FEBS Microbiol. Lett. 317: 6-100.

ZApomĚLOVÁ, E. (2008): Anabaena. Phenotypic and genotypic diversity of planktonic strains in fishponds and reservoirs of the Czech Republic [Ph.D. thesis]. - 125 pp., University of South Bohemia in České Budějovice, Faculty of Science,.

Zapomělová, E.; ŘehÁKová, K.; Znachor, P. \& KomÁrKovÁ, J. (2007): Morphological diversity of coiled planktonic types of the genus Anabaena (cyanobacteria) in natural populations - taxonomic consequences. Crypt. Algol. 28: 353-371.

Zapomělová, E.; Hisem, D.; ŘehákovÁ, K.; HrouzeK, P.; JezBerová, J.; KomÁrková, J.; Korelusová, J. \& ZnACHOR, P. (2008): Experimental comparison of phenotypical plasticity and growth demands of two strains from the Anabaena circinalis / A. crassa complex (cyanobacteria). - J. Plank. Res. 30: 1257-1269.

Zapomělová, E.; Jezberová, J.; Hrouzek, P.; Hisem, D.; ŘehÁkovÁ, K. \& KomÁrková, J. (2009): Polyphasic characterization of three strains of Anabaena reniformis and Aphanizomenon aphanizomenoides (cyanobacteria) and their re-classification to Sphaerospermum gen. nov. (incl. Anabaena kisseleviana). - J. Phycol. 45: 1363-1373.

Zapomělová, E.; Jezberová, J.; Hrouzek, P.; Hisem, D.; ŘeHÁKovÁ, K. \& KomÁrKovÁ, J. (2010a): Polyphasic characterization of three strains of Anabaena reniformis and Aphanizomenon aphanizomenoides (cyanobacteria) and their re-classification to Sphaerospermum gen. nov. (incl. Anabaena kisseleviana). Nomenclatural Note. - J. Phycol. 46: 415.

ZapomĚlovÁ, E.; ŘehÁKovÁ, K.; JeZBerovÁ, J. \& KomÁrKovÁ, J. (2010b): Polyphasic characterization of eight planktonic Anabaena strains (cyanobacteria) with reference to the variability of 61 Anabaena populations observed in the field. - Hydrobiologia 639: 99-113.

Zapomělová, E.; Hrouzek, P.; Řezanka, T.; Jezberová, J.; ŘehÁKovÁ, K.; Hisem, D. \& KomÁrKovÁ, J. (2011): Polyphasic characterization of Dolichospermum spp. and Sphaerospermopsis spp. (Nostocales, Cyanobacteria): morphology, 16S rRNA gene sequences and fatty acid and secondary metabolite profiles. - J. Phycol. 47: 1152-1163.

Zapomělová, E.; SkÁcelová, O.; Pumann, P.; Kopp, R. \& JANEČEK, E. (2012): Biogeographically interesting planktonic Nostocales (Cyanobacteria) in the Czech Republic and their polyphasic evaluation resulting in taxonomic revisions of Anabaena bergii Ostenfeld 1908 (Chrysosporum gen. nov.) and A. tenericaulis Nygaard 1949 (Dolichospermum tenericaule comb. nova). - Hydrobiologia 698: 353-365.

(C) Czech Phycological Society (2016)

Received September 7, 2015

Accepted March 21, 2016 